Erratum

\title{
Erratum to "Association of Tissue Transglutaminase Antibody Titer with Duodenal Histological Changes in Children with Celiac Disease"
}

\author{
Hasan Hawamdeh $\mathbb{D D}^{1,2}$ Basim Al-Zoubi, ${ }^{2}$ Yasameen Al Sharqi ${ }^{1},{ }^{3}$ Ayman Qasrawi $\left(\mathbb{D},{ }^{2}\right.$ \\ Yousef Abdel-Aziz $\left(\mathbb{D},{ }^{2}\right.$ and Maha Barbar $\mathbb{D}^{1,2}$ \\ ${ }^{1}$ Department of Pediatrics, Hashemite University, P.O. Box 1504514, Zarqa 13115, Jordan \\ ${ }^{2}$ Department of Pediatrics, Prince Hamzah Hospital, P.O. Box 86, Amman 11118, Jordan \\ ${ }^{3}$ Department of Pathology, Prince Hamzah Hospital, P.O. Box 86, Amman 11118, Jordan \\ Correspondence should be addressed to Maha Barbar; mahabarbar@yahoo.com
}

Received 21 March 2019; Accepted 25 March 2019; Published 14 April 2019

Copyright (c) 2019 Hasan Hawamdeh et al. This is an open access article distributed under the Creative Commons Attribution License, which permits unrestricted use, distribution, and reproduction in any medium, provided the original work is properly cited.

In the article titled "Association of Tissue Transglutaminase Antibody Titer with Duodenal Histological Changes in Children with Celiac Disease" [1], the name of the fifth author was given incorrectly as Yousef Abdelaziz. The author's name should have been written as Yousef Abdel-Aziz. The revised authors' list is shown above.

\section{References}

[1] H. Hawamdeh, B. Al-Zoubi, Y. Al Sharqi, A. Qasrawi, Y. Abdelaziz, and M. Barbar, "Association of tissue transglutaminase antibody titer with duodenal histological changes in children with celiac disease," Gastroenterology Research and Practice, vol. 2016, Article ID 6718590, 6 pages, 2016. 


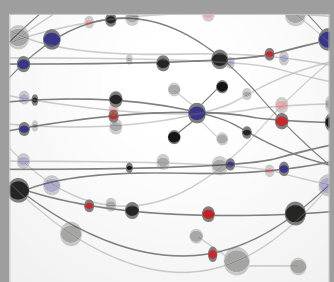

The Scientific World Journal
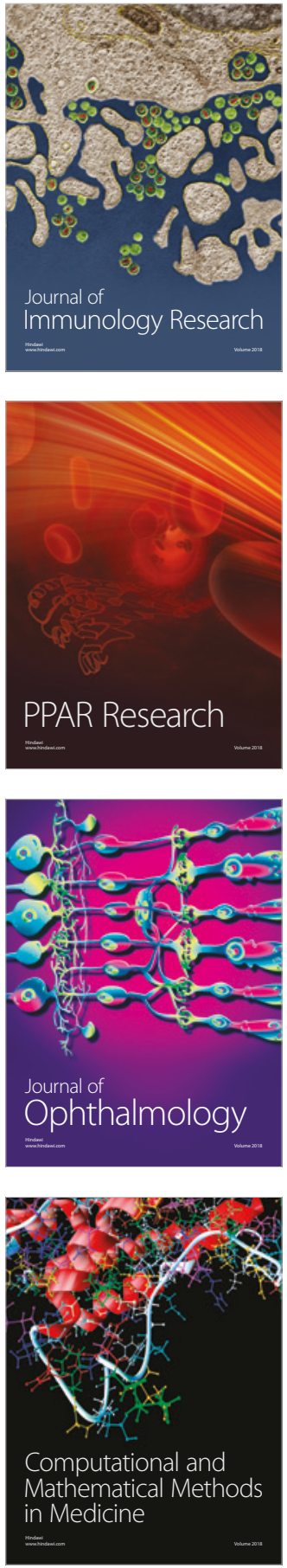

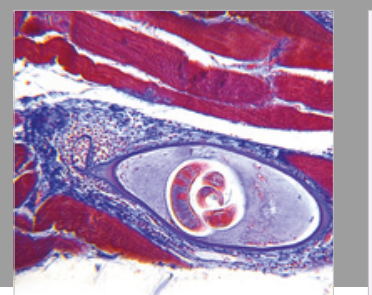

Gastroenterology Research and Practice

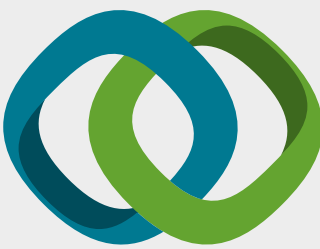

\section{Hindawi}

Submit your manuscripts at

www.hindawi.com
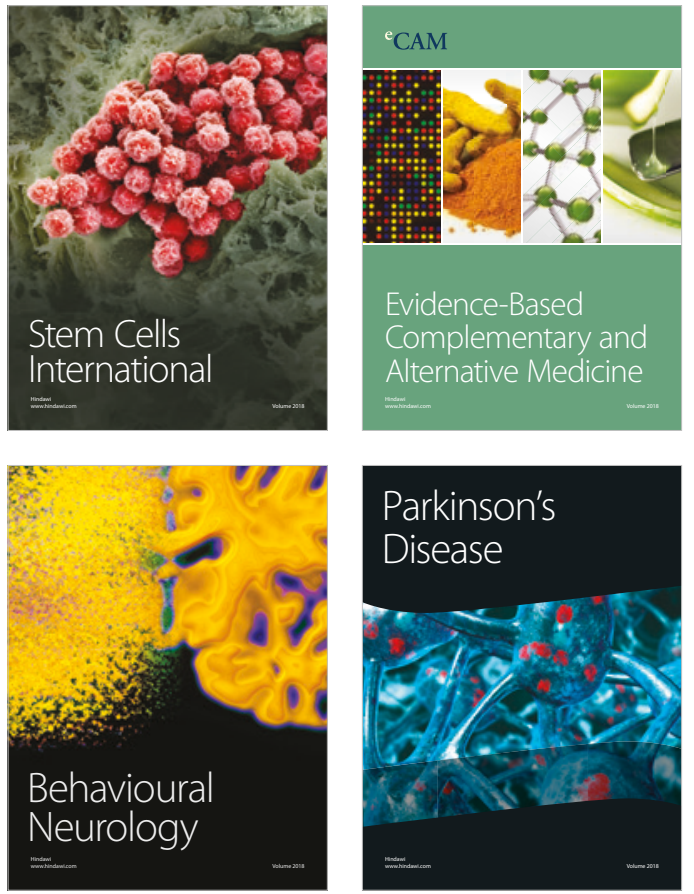

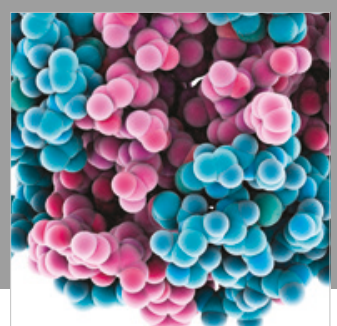

ournal of

Diabetes Research

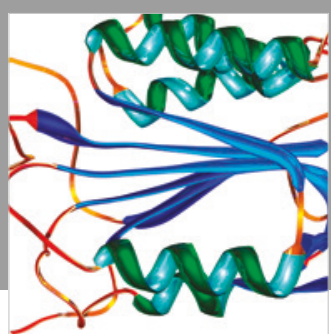

Disease Markers
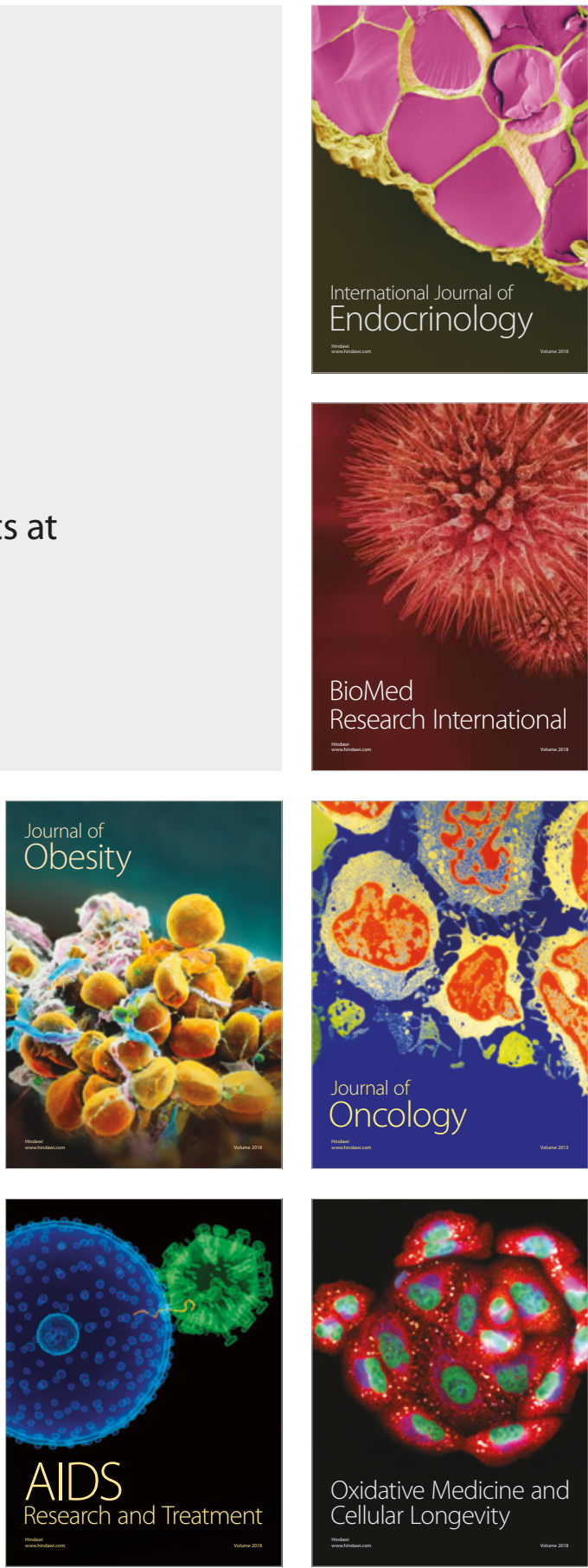